\title{
Çay çöpünden kompost yapımı ve oluşan kompostun bazı özellikleri
}

\section{Composting of tea waste and some properties of compost}

\author{
Nuray Mücellâ MÜFTÜOĞLU®, Cafer TÜRKMEN@, Yasemin KAVDIR『 \\ Çanakkale Onsekiz Mart Üniversitesi, Ziraat Fakültesi, Toprak Bilimi ve Bitki Besleme Bölümü, 17100, Çanakkale \\ Sorumlu yazar (Corresponding author): N. M. Müftüoğlu, e-posta (e-mail): mucella@comu.edu.tr \\ Yazar(lar) e-posta (Author e-mail): turkmen@comu.edu.tr, kavdirya@comu.edu.tr
}

\section{MAKALE BİLGİSİ}

Alınış tarihi 12 Mart 2019

Düzeltilme tarihi 19 Nisan 2019

Kabul tarihi 26 Nisan 2019

Anahtar Kelimeler:

Çay çöpü

Kompost

$\mathrm{C} / \mathrm{N}$

Besin Elementi

\section{ÖZ}

$\mathrm{Bu}$ araştırma, çay fabrikalarından elde edilen çay çöpü atıklarından kompost yapımı sürecinin kısaltılması ve oluşan kompostun temel özelliklerinin belirlenmesi amacıyla yürütülmüştür. $\mathrm{Bu}$ amaç için; Çanakkale Onsekiz Mart Üniversitesi (ÇOMÜ) Teknoloji ve Tarımsal Araştırma Uygulama Merkezi (TETAM)'nde kurgulanan çalışmada çay fabrikalarından elde edilen çay atıkları taze keçi gübresi, kuru yonca ve su ile karıştırılmıştır. Karışım, sıcaklık ve hava kontrollü otomatik reaktörlere doldurularak kompost yapımı süresi boyunca karışımın sıcaklığı, nemi ve hava sıcaklıkları düzenli sekilde takip edilmiștir. Her sıcaklık azalmas sırasında açılan tanktan örnek alınarak $\mathrm{pH}, \mathrm{EC}, \% \mathrm{C}, \% \mathrm{~N}$ değerleri ile $\mathrm{C} / \mathrm{N}$ oranı analizleri takip edilmiş, hazır hale gelen komposttan son bir örnek alınarak bazı element $(\mathrm{P}, \mathrm{K}, \mathrm{Ca}, \mathrm{Mg}$, $\mathrm{Fe}, \mathrm{Cu}, \mathrm{Zn}, \mathrm{Mn}, \mathrm{B}, \mathrm{Na}$ ) analizleri yapılmıștır. Elde edilen verilere göre; kompost öncesi kullanılan çay atığının pH değeri 5.48 den 6.89 değerine yükselirken, suda eriyebilir tuz 1.885 $\mathrm{dS} \mathrm{m} \mathrm{m}^{-1}$ değerinden $1.690 \mathrm{dS} \mathrm{m}^{-1}$ değerine düşmüştür. Takip edilen $\mathrm{C}$ ve $\mathrm{N}$ değerleri çay atığında $\% 45.54$ ve $\% 1.58$ olup $\mathrm{C} / \mathrm{N}$ değeri 28.82 iken, kompostlaşma süreci sonunda alınan örnekte bu değerlerler $\% 45.55$ ve $\% 2.57$ olup $\mathrm{C} / \mathrm{N}$ oranı 17.70 değerine düşmüştür. Element içerikleri ise P: 2659, $\mathrm{K}: 17146, \mathrm{Ca}: 7990, \mathrm{Mg}: 2766, \mathrm{Fe}: 185, \mathrm{Cu}: 15, \mathrm{Zn}: 38, \mathrm{Mn}: 832$, B: 30, Na: $669 \mathrm{mg} \mathrm{kg}^{-1}$ olarak tespit edilmiştir. Elde edilen verilere göre çay çöpü kompostunun kısa sürede oluşturulabileceği ve tarımda kullanılabileceği kanaatine varılmıștır.

\section{ARTICLE INFO}

Received 12 March 2019

Received in revised form 19 April 2019

Accepted 26 April 2019

\section{Keywords:}

Tea waste

Compost

$\mathrm{C} / \mathrm{N}$

Nutrient

\begin{abstract}
This study was carried out with the aim of shortening the process of composting from the tea wastes obtained from the tea factories and determining the main characteristics of the compost. For this purpose; In the study conducted in Çanakkale Onsekiz Mart University (ÇOMÜ) Technology and Agricultural Research Application Center (TETAM), tea wastes from tea factories were mixed with fresh goat manure, dry alfalfa and water. The mixture was filled into temperature and air-controlled automatic reactors and the temperature, humidity and air temperatures of the mixture were monitored regularly during the composting period. $\mathrm{C} / \mathrm{N}$ ratio analyzes with $\mathrm{pH}, \mathrm{EC}, \mathrm{C} \%, \mathrm{~N} \%$ values have been followed by taking samples from the tanks opened during each temperature decrease, and some elements $(\mathrm{P}, \mathrm{K}, \mathrm{Ca}, \mathrm{Mg}, \mathrm{Fe}, \mathrm{Cu}, \mathrm{Zn}, \mathrm{Mn}$, $\mathrm{B}, \mathrm{Na}$ ) analyzes were performed. According to the data obtained; while the $\mathrm{pH}$ value of the tea waste used before the compost increased from 5.48 to 6.89 , the water soluble salt decreased from $1.885 \mathrm{dS} \mathrm{m}^{-1}$ to $1.690 \mathrm{dS} \mathrm{m}^{-1}$. The $\mathrm{C}$ and $\mathrm{N}$ values of the tea waste litter were $45.54 \%$ and $1.58 \%$ and the $\mathrm{C} / \mathrm{N}$ value was 28.82 , while the $\mathrm{C}$ and $\mathrm{N}$ values of the tea waste compost were $45.55 \%$ and $2.57 \%$ and $\mathrm{C} / \mathrm{N}$ value was 17.70 . Elemental contents were determined as $\mathrm{P}$ : 2659, K: 17146, Ca: 7990, Mg: 2766, Fe: 185, Cu: 15, Zn: 38, Mn: 832, B: 30, Na: 669 $\mathrm{mg} \mathrm{kg}^{-1}$. According to the data obtained, it is concluded that tea waste compost can be formed in a short time and it can be used in agriculture.
\end{abstract}

\section{Giriș}

Çay, Türkiye ekonomisi için olduğu kadar Doğu Karadeniz Bölgesinin ekonomisi ve sosyal yaşamı için de vazgeçilmez bir üründür. Ülkemizde çay tarımı; Doğu Karadeniz Bölgesinde Rize, Artvin, Trabzon, Giresun ve Ordu illerini kapsayan toplam 767000 dekar alanda yapılmaktadır. Türkiye'deki çay yetiștiriciliği yapılan tarım alanlarının \%11'i Artvin, \%65' Rize, \%21'i Trabzon ve \%3'ü ise Giresun ve Ordu illerinde yer almaktadır. Çay tarımı topraklarının Türkiye geneli topraklara göre farklılıklara sahip olması nedeni ile özelliklerinin korunmasına dikkat edilmelidir. Çay bitkisi bölge için çok 
önemli bir ürün olması nedeni ile çay bitkisinin istekleri göz önünde tutularak işlem yapılmalıdır. $\mathrm{Bu}$ işlemlerin en önemlilerinden biri gübrelemedir (Müftüoğlu ve ark. 2012a).

Çay bitkisinin ekonomik olarak 30 kadar ülkede yetiştiriciliği yapılmaktadır. Ülkemiz çay yetiştirilen alanlar bakımından yedinci, üretilen mamul çay bakımından beşinci sırada bulunmakta; tüketim olarak ise kişi başına yılda yaklaşık $2.5 \mathrm{~kg}$ ile ikincilik ile dördüncülük arasında yer almaktadır. Ülkemizde çay yetiştiriciliği yapılan alanların \%93'ü 0-500 m yükseltilerde, $\% 95$ 'i sahilden $25 \mathrm{~km}$ içeriye kadar yayılmaktadır. Çay bahçelerinin \%9'u ekonomik ömür kabul edilen 50 yaş üzerindedir. Bölgenin coğrafi karakteri nedeniyle çay bahçeleri düz alanlardan sarp alanlara kadar değişen farklı eğimli yerlerde kurulmuştur. Ülkemizdeki çay bahçelerinin tamamı tohumla tesis edilmiştir. Tohumdaki açılımlar nedeniyle çay bahçelerimiz, nitelik ve verim bakımından farklı karakterler gösteren çay bitkilerinden oluşmuştur (Müftüoğlu ve ark. 2012b).

Ülkemizde gerek tarımsal ürünleri ișleyen gerekse tarımsal aktivitede bulunan çeşitli işletmelerden her y1l önemli oranda ve değişik özelliklere sahip atıklar ortaya çıkmaktadır. Bu atıklar çoğu zaman işletmelerin çalışma sahalarında büyük alanlar işgal ederek iş düzeninin aksamasına yol açabilmektedir. Çay yaprağ 1 işleyen fabrikalarda yılda yaklaşık olarak 20 bin tonun üzerinde çay atığı çıkmaktadır (Kacar 1987). Çay imalatı ile oluşan binlerce ton atık miktarı üreticiden alınan çay bitkisinin tazelik durumuna göre değişmektedir. Çay bahçelerinden çay alım yerleri ve fabrikalara gelen ham madde ne kadar taze olursa oluşan çay atık miktarı da o oranda azalmaktadır.

Çay atıkları ile ilgili değişik çalışmalar yapılmış bulunmaktadır. Bu çalışmalara; çay fabrikalarındaki imalat atığında kompostlaştırma (Yalınkılıç ve ark. 1996; Kacar ve ark. 2004; Özyazıcı 2013), oluşan kompostu zenginleştirme (Kacar ve ark. 1996), kompost hale getirdikten sonra bu kompostu tarımda kullanma (Kacar ve ark. 1980; Kütük ve ark. 1995; Kütük ve ark. 1996; Altun 1998; Kütük 2000; Aşık ve Kütük 2012), pellet hale getirme (Dok 2014; Bilgin ve ark. 2016), konularındaki çalışmalar sıralanabileceği gibi, siyah çayın demlendikten sonraki posası üzerinde de bir araştırmaya (Irmak ve Müftüoğlu 2016) rastlanmıştır.

Bu çalışmada farklı olarak; kurulacak sıcaklık kontrollü otomatik havalandırmalı bir dizi reaktör düzeneği ile en kısa sürede çay atıklarını kompostlaştırmak, çay fabrikaları atıklarının yol açtı̆̆ problemleri hızla azaltmak ve oluşan kompostun temel özelliklerini ve gübre değerinin kontrollü şartlarda belirlenmesi amaçlanmıştır. $\mathrm{Bu}$ sayede sürekli kimyasal gübrelerle gübrelenen çay alanlarına yine çay bitkisinden üretilen kompostun ilavesi ile organik çay tarımı literatürüne katkıda bulunmak amaçlanmıştır.

\section{Materyal ve Yöntem}

\subsection{Materyal}

Çay atığı; fabrikalarda çay imalatı tasnif bölümünde, eleğe alınan çay bitkisinin tazeliğine bağlı olarak elek üstünde kalarak ayrılan çay bitkisinin daha lifli ve selüloz miktarı daha fazla olan çöplü kısmıdır. Denemede kullanılan çay atığı Çay İşletmeleri Genel Müdürlüğü'ne (ÇAY-KUR) bağlı Çay Araştırma Enstitüsü'nden temin edilmiştir. Denemede ayrıca taze keçi gübresi, kuru yonca ve musluk suyu kullanılmıştır. Keçi gübresi ve kuru yonca ÇOMÜ-TETAM'dan temin edilmiştir. Deneme başlangıcında kullanılan çay atığının karbon/azot $(\mathrm{C} / \mathrm{N})$ oranı belirlenmiştir. Deneme başlangıcında kullanılan materyal cinsleri, miktarları ve örnekleme zamanları Çizelge 1'de verilmiştir.

\subsection{Yöntem}

Çay çöpü atı̆̆ına herhangi bir işlem uygulanmamış, Rize ÇAY-KUR'dan geldiği gibi kuru haliyle tartılarak bir branda üzerine konulmuş, keçi gübresi ÇOMÜ-TETAM'daki ağılda barınan hayvanların altından taze olarak alınan gübreden çay çöpünün yaklaşık \%10'u kadar tartılarak çay çöpü üzerine eklenmiştir. Karışımın pH'sı ve $\mathrm{C} / \mathrm{N}$ oranının dengelenmesi amaciyla \%10 kadar kuru yonca kaba olarak (saman boyutlarında) öğütülmüş, tartılmış ve çay atığı ile keçi gübresi üzerine elle serpilmiştir. Deneme kurulurken kullanılan 12 litre suyun 6 litresi genişçe bir kova içerisine alınan karışımın bir tahta yardımı ile iyice karıştırılması şeklinde; kalan 6 litresi de yavaş yavaş tekrar branda üzerine alınan karışımın üzerine homojen bir şekilde verilmiştir (Şekil 1a).

Çay atığı, keçi gübresi, kuru yonca ve sudan oluşan karışım tırmık/kürek gibi araçlarla karıştırılıp homojenize edildikten sonra karışımın üç yerinden yaklaşık 100 er gram temsili örnek alınarak laboratuvara aktarılmıştır. Geri kalan materyal sürecin başlatılması için otomatik havalandırmalı ve sıcaklık kontrollü reaktörlere dört tekrarlı olacak şekilde eşit miktarlarda doldurulmuştur. Reaktör sistemi 4 adet ve hacmi 1001 olan paslanmaz çelikten silindirik formda yapılmıştır (Şekil 1b).

Reaktörlerde giriş havasının kompost materyalinde düzgün olarak dağılımını sağlamak için, reaktör taban boşluğu oluşturulmuştur ve boşluk üzerine kompostları yerleştirmek için $4 \mathrm{~mm}$ delikli saç malzeme eklenmiştir. Kompost ve ortam s1caklığ1 1sıya duyarlı (thermocouple) sensörler ile veri kaydedici üniteye (data logger)'a 5 dakika aralıklarla kaydedilmiş̧ir. Haftada üç kere kompost materyali su tutma

Çizelge 1. Denemede kullanılan materyaller, miktarları ve örnek alınma zamanları.

Table 1. Used materials in the experiment, its quantities and sampling times.

\begin{tabular}{|c|c|c|c|c|}
\hline Kullanılan materyal & Miktar & Günler & Örnek no & Açıklama \\
\hline Çay atığı & $13000 \mathrm{~g}$ & \multirow{4}{*}{ 1. gün } & \multirow{4}{*}{1} & \multirow{4}{*}{ Deneme kurulumunda } \\
\hline Taze keçi gübresi & $1500 \mathrm{~g}$ & & & \\
\hline Kuru yonca & $1100 \mathrm{~g}$ & & & \\
\hline \multirow{6}{*}{$\mathrm{Su}$} & $12000 \mathrm{~mL}$ & & & \\
\hline & $5000 \mathrm{~mL}$ & 7. gün & 2 & 1. karıştırma \\
\hline & $4000 \mathrm{~mL}$ & 11. gün & 3 & 2. karıştırma \\
\hline & $3000 \mathrm{~mL}$ & 18. gün & 4 & 3. karıştırma \\
\hline & & 25. gün & 5 & 4. karıştırma ve sonlandırma \\
\hline & & 33. gün & 6 & 4. karıştırmadan 1 hafta sonra \\
\hline
\end{tabular}



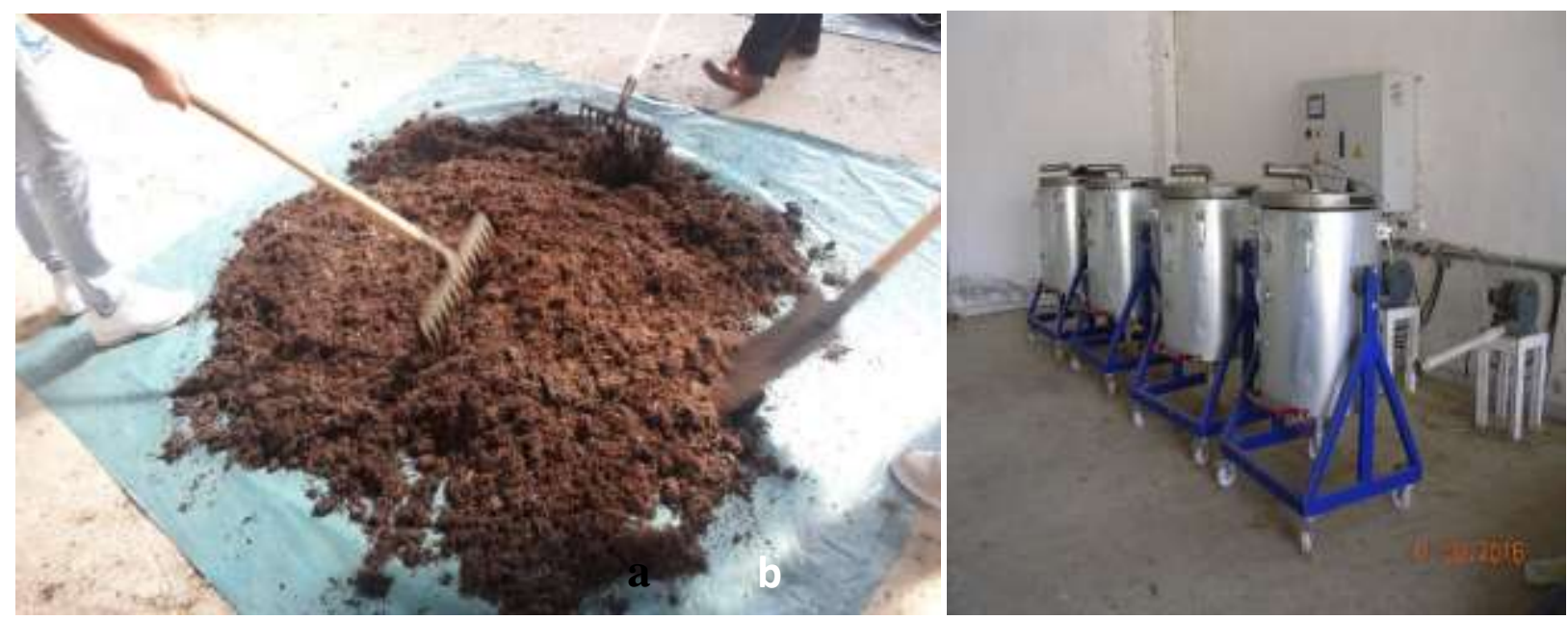

Şekil 1. Karışımın hazırlanması (a) ve otomatik hava kontrollü reaktörler (b).

Figure 1. Preparation of the mixture (a) and air-controlled automatic reactors (b).

kapasitesinin yarısı kadar 1slatılıp karıştırılmıştır. Kompost sıcaklığının ölçülmesi $\mathrm{K}$ tipi 1 sıl çift amplifikatörü ile gerçekleştirilmiştir. Her bir reaktör üzerinde 3 adet 1 sıl çift olmak üzere sistemde toplam 45 adet 1 sıl çift bulunmaktadır. Ölçülen sicaklıklar kompostlama işleminin takibi ve kontrolü amaçlı olarak PLC de TC modülüne bağlanmıştır.

Karışımın elle sıkıldığında avuç içini ıslatacak kadar nem içerdiği görülene dek ölçülü miktarlarda su verme ve aktarma/karıştırma işlemleri sürdürülmüştür. $\mathrm{Bu}$ esnada karışımın nem değerinin yaklaşık $\% 50$ olduğu, takiben laboratuvarda yapılan nem tayinleri ile anlaşılmıştır. Her karıştırma ve örnekleme zamanında eksilen karışım nemi yine elle muayene usulü ile tamamlanmıştır. Her karıştırma sonrası alınan örneklerde nem tayinleri izlenerek ortalama karışımın nemlerinin \%50-60 arasında değiştiği anlaşılmıştır.

Deneme kurulumundan sonraki bir hafta boyunca her gün sabah ve akşam günde iki kez, reaktör pano göstergelerindeki reaktör içi alt orta ve üst bölüm sıcaklıkları takip edilmiştir. İlk günlerde hızla yükselen reaktör içi orta bölüm sıcaklıkları 7 .

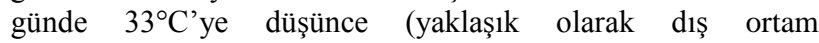
sıcaklıklarına kadar düşünce) reaktör tankları boşaltılmış, yeteri kadar sulandırılmış (5 litre), karışım homojenize edilerek örnekler alınmış ve materyal reaktör tanklarına yeniden doldurulmuştur (Şekil 2).

Her örneklemede alınan materyallerin nem analizleri, $\mathrm{pH}$ ve suda eriyebilir tuz değerleri 1:10 oranındaki (materyal:saf su) karışımda ölçülmüştür (Jackson 1958).

Günlük olarak izlenen reaktör sıcaklıklarının düşmesi nedeniyle tanklar boşaltılmış denemenin 11. günü 4 litre ve 18 . günü 3 litre su eklenen karışımlar homojen şekilde karıştırılıp tanklara konulmadan her seferinde örneklenmiş ve laboratuvara nakledilmiştir. Denemenin 25. Gününde ise yine reaktörlerdeki sıcaklık düşmesi sonucu tanklar boşaltılmış, nem durumu yeterli olduğu için su eklenmemiş, karıştırılıp örnekler alındıktan sonra artık kompost özellikleri gösteren materyal gölgede branda üzerinde yığın halinde bir süre daha bırakılmıştır.

Denemenin 33. günü son örnekleme olan 6. örnekleme yapılmış ve yaş yakılan örneklerde ÇOMÜ-ÇOBİLTUM laboratuvarlarında ICP-OES yardımıla makro-mikro besin element analizleri yapılmıştır (Kacar ve İnal 2010). ÇOMÜZiraat Fakültesi Toprak Bilimi ve Bitki Besleme laboratuvarlarında ise diğer analizler Müftüoğlu ve ark. (2014) göre yapılmıştır.

\section{Bulgular}

Deneme kurulumundan kompost oluşana kadar günlük olarak kompost sicaklıkları reaktörlerin alt, orta ve üst kısmından ve dış ortam sıcaklıkları kaydedilmiştir ve binden fazla ölçüm alınmıştır. Bu ölçümlerde karışımın sıcaklıkları reaktörlerin üst kısımlarında $24.8-62.4^{\circ} \mathrm{C}$ arasında değişmiş, ortalama $44.8^{\circ} \mathrm{C}$ olmuştur. Reaktörlerin orta kısmında karışımın sıcaklığ $25.1-60.2^{\circ} \mathrm{C}$ arasında değişmiş ve ortalama $45.5^{\circ} \mathrm{C}$ olmuştur. $\mathrm{Bu}$ sıcaklıklar reaktörlerdin alt kısımlarında 23.9$56.7^{\circ} \mathrm{C}$ arasında değişmiş, ortalama $40.7^{\circ} \mathrm{C}$ olarak belirlenmiştir.

Başlangıçta reaktör içi ortalama karışım sıcaklığ $29.2^{\circ} \mathrm{C}$ olup, 5. gün $55.4^{\circ} \mathrm{C}$ ye kadar yükselmiş ve 7 . Güne kadar $25.3^{\circ} \mathrm{C}$ ye düşünce reaktör boşaltılarak 1 . karıştırma ve su verme işlemi yapılmıştır. Tekrar reaktör tanklarına alınan materyallerin sıcaklıkları yeniden yükselerek 8 . gün $57.7^{\circ} \mathrm{C}$ ye kadar ulaşmış ve 11 . günde $28.2^{\circ} \mathrm{C}$ ye düşünce 2 . karıştırma yapılmıştır. Sicaklık 15. güne kadar $56.8^{\circ} \mathrm{C}$ ye yükselmiş ve 18 . güne kadar da $28.4^{\circ} \mathrm{C}$ ye düşünce 3 . karıştırma yapılmıştır. Yeniden tanklara alınan materyalin 21. günde sıcaklıkları $42.0^{\circ} \mathrm{C}$ ye kadar yükselmiş ve 25 . günde sicak $28.7^{\circ} \mathrm{C}$ ye düşünce reaktörler boşaltılmış yapılan elle muayene sonrası kompostlaşmanın tamamlandığı görülünce denemeye son verilmiştir.

Deneme süresince dış hava sıcaklıkları gün içindeki değişimlerle birlikte $23.4-42.5^{\circ} \mathrm{C}$ arasında değişmiş, ortalama $32.3^{\circ} \mathrm{C}$ olarak belirlenmiştir. Reaktörlerin içinde bulunan karışımın nem değerleri ise \%24.4-73.7 arasında değişmiş, ortalama \%52.3 olarak ölçülmüştür (Şekil 3).

Reaktör tankları son kez boşaltıldıktan sonra oluşan kompost bir hafta gölgede branda üzerinde yığın şeklinde bekletilerek olgunlaştırılmış ve 33. günde son bir örnekleme daha yapılmıştır.

Deneme başlangıcında çay atığının $13 \mathrm{~kg}$ olduğu göz önüne alındığında ve sonuçta yaklaşık $10 \mathrm{~kg}$ kompost elde edildiğine göre çay atı̆̆ının yaklaşık \%75 inin komposta dönüştüğü görülmektedir. Çay atığına su dahil tüm diğer malzemeler katıldığında 27.6 kg olan karışımın örneklemeler için ayrılan 1.1 kg'lık miktarı çıkarıldıktan sonra $26.5 \mathrm{~kg}$ kaldığ 1 ve bu 

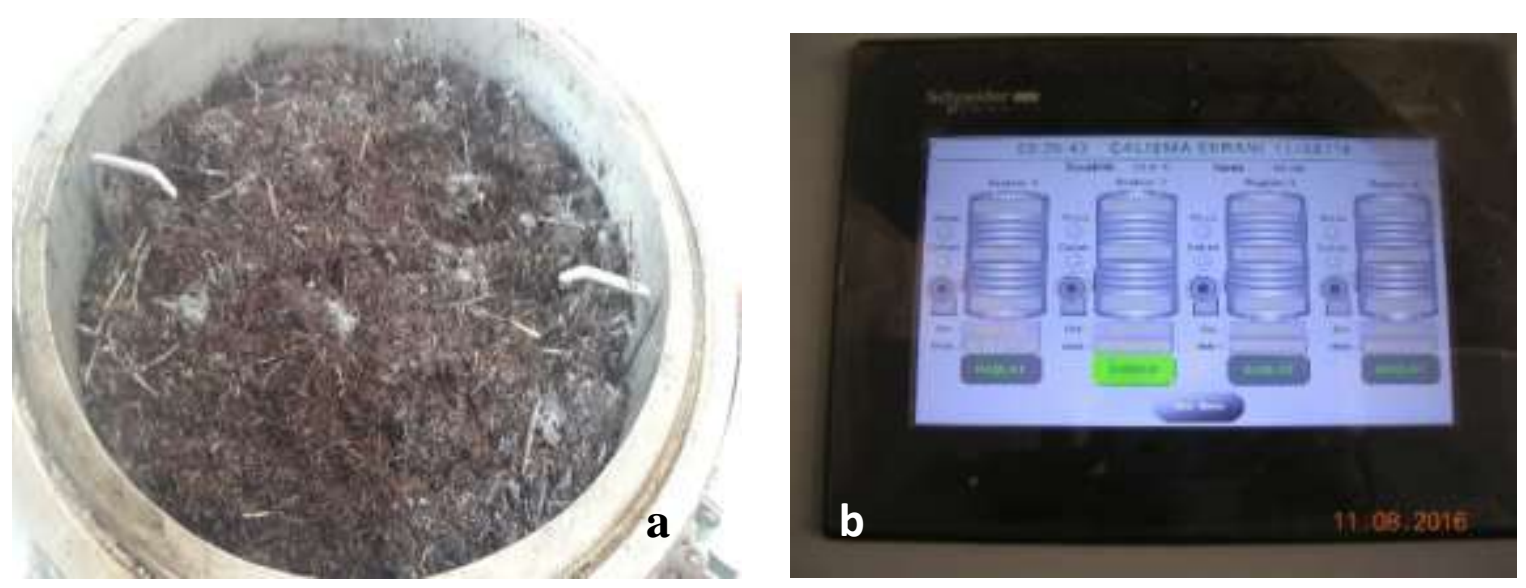

Şekil 2. Reaktör tankındaki karışım (a) ve kontrol paneli (b).

Figure 2. Mixture (a) and control panel (b) in reactor tank.

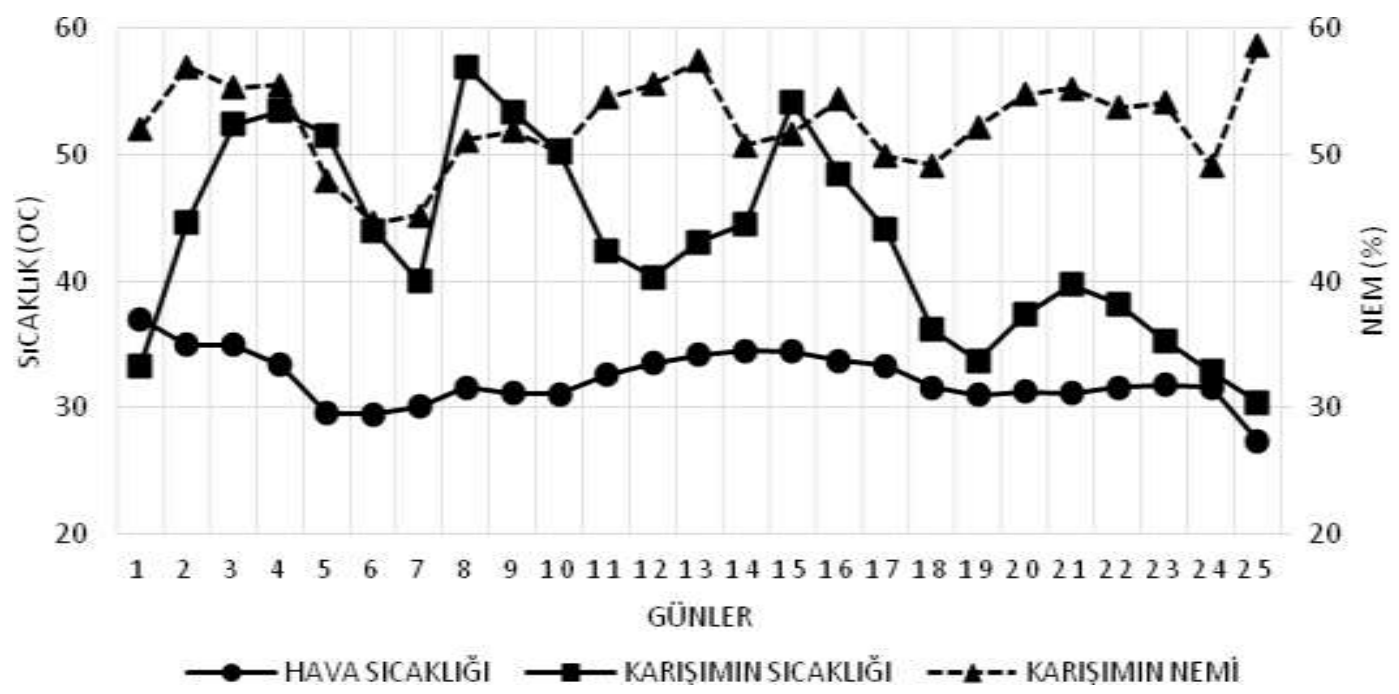

Şekil 3. Reaktör içi sıcaklığı, dış hava sıcaklığı ve nem değerleri

Figure 3. The values of temperature inside reactor, outside air temperature, and humidity.

miktardan elde edilen kompost miktarının $14 \mathrm{~kg}$ olduğu görülmüştür. $\mathrm{Bu}$ durum çay atı̆̆ından elde edilen kompostun başlangıçtaki su dahil tüm materyalin yaklaşık \%53 olduğunu, yani kısaca çay atıklarının bu yolla kompost haline getirilmesinde toplam ağırlıklarının yarısı kadar kompost elde edilebileceğini görülmüştür.

Deneme başlangıcında çay atığının 28.82 olan $\mathrm{C} / \mathrm{N}$ oranı diğer malzemelerin katılması ile 27.39 değerine gerilemiştir; deneme sonlandırıldığında 22.31 değerine ve olgunlaşan kompostta ise bu oranın 17.70 değerine düştüğü görülmektedir. Elde edilen kompostun $\mathrm{pH}$ değeri 6.89, elektriksel iletkenliği de $1.690 \mathrm{dS} \mathrm{m}^{-1}$ olarak ölçülmüştür (Çizelge 2).

Özyazıcı (2013) tarafindan kontrolsüz koşullarda oluşturulan çay atığı kompostunun $\mathrm{pH}$ değerinin 6.99 ; tuz değerinin $2.09 \mathrm{dS} \mathrm{m} ~ m^{-1}$; organik karbon içeriğinin \%51.281; toplam azot içeriğinin \%5.272 ve $\mathrm{C} / \mathrm{N}$ değerinin 9.72 olduğu belirtilmektedir.

Aşık ve Kütük (2012) benzer koşullarda yaptıkları çalışmada çay atığı kompostunun $\mathrm{pH}$ değerinin 7.50 ; tuz değerinin $1.332 \mathrm{dS} \mathrm{m} \mathrm{m}^{-1}$; organik karbon içeriğinin \%27.40; toplam azot içeriğinin \%2.35 ve $\mathrm{C} / \mathrm{N}$ değerinin 11.60 olduğu belirtmişlerdir.

Elde edilen kompostun içerdiği bazı makro-mikro besin elementlerinin miktarları dikkate alınarak dekara 1 ton hesabı ile çaylıklara verilmesi durumunda sağlayacakları besin maddesi miktarları Çizelge 3'de verilmiştir.

Elde edilen kompostun 23 Şubat 2018 tarih ve 30341 sayılı Resmî Gazetede yayınlanmış olan "Tarımda Kullanılan Organik, Mineral ve Mikrobiyal Kaynaklı Gübrelere Dair Yönetmelik" ile istenmiş olan koşulları sağladığı belirlenmiştir (Resmî Gazete 2018).

Özyazıcı (2013) yaptığı çalışmada çay atığı kompostunun P içeriği 2490, K içeriği 13900, Ca içeriği 2500, Mg içeriği 2700, Fe içeriği 369, Cu içeriği $17, \mathrm{Zn}$ içeriği $37, \mathrm{Mn}$ içeriğinin 1417 $\mathrm{mg} \mathrm{kg}^{-1}$ olduklarını belirtmiştir.

Aşık ve Kütük (2012) tarafindan yapılan çay atığı kompostunun toplam $\mathrm{P}_{2} \mathrm{O}_{5}$ içeriğinin $2900 \mathrm{mg} \mathrm{kg}^{-1}$, toplam $\mathrm{K}_{2} \mathrm{O}$ 
Çizelge 2. Kompostlaşma sürecinde $\mathrm{C}, \mathrm{N}, \mathrm{C} / \mathrm{N}, \mathrm{pH}$ ve $\mathrm{EC}$ değişimleri.

Table 2. Changes of $\mathrm{C}, \mathrm{N}, \mathrm{C} / \mathrm{N}, \mathrm{pH}$, and $\mathrm{EC}$ in the composting process.

\begin{tabular}{|c|c|c|c|c|c|c|c|}
\hline Örnek no & Gün & Örnekleme aşamaları & $\mathrm{C}(\%)$ & $\mathbf{N}(\%)$ & $\mathrm{C} / \mathrm{N}$ & pH & $\mathrm{EC}\left(\mathrm{dS} \mathrm{m}^{-1}\right)$ \\
\hline 1 & 1. & Başlangıç & 44.54 & 1.63 & 27.39 & 5.48 & 1.885 \\
\hline 2 & 7. & 1. karıştırma & 43.71 & 1.85 & 23.65 & 6.38 & 1.691 \\
\hline 3 & 11. & 2. karıştırma & 45.67 & 1.59 & 28.76 & 6.97 & 1.750 \\
\hline 4 & 18. & 3. karıştırma & 45.20 & 2.23 & 20.23 & 6.53 & 1.765 \\
\hline 5 & 25. & 4. karıştırma & 42.39 & 1.90 & 22.31 & 6.80 & 1.391 \\
\hline 6 & 33. & Kompost & 45.55 & 2.57 & 17.70 & 6.89 & 1.690 \\
\hline
\end{tabular}

Çizelge 3. Kompostun 10 ton ha $^{-1}$ uygulanması ile katıldığı ortama katkısı.

Table 3. Contribution of the compost to the medium with application of 10 tones ha-1.

\begin{tabular}{cccccccccccccc}
\hline \multicolumn{10}{c}{ Besin elementi katkısı (g da-1) $^{-1}$} \\
\hline $\mathrm{P}$ & $\mathrm{K}$ & $\mathrm{Ca}$ & $\mathrm{Mg}$ & $\mathrm{Fe}$ & $\mathrm{Cu}$ & $\mathrm{Zn}$ & $\mathrm{Mn}$ & $\mathrm{B}$ & $\mathrm{Na}$ \\
\hline 2659 & 17146 & 7990 & 2766 & 185 & 15 & 38 & 832 & 30 & 669 \\
\hline
\end{tabular}

içeriğinin ise $8300 \mathrm{mg} \mathrm{kg}^{-1}$ olduğu belirtilmişlerdir. Kompost oluşum aşamaları farklı olan kompostların besin elementleri içeriklerindeki farklılıklar doğal karşılanmalıdır.

Yakupoğlu ve Özdemir (2007) tarafindan yapılan denemede kullanılan çay atığının \%54.78 organik $\mathrm{C}$ ve $\% 2.45 \mathrm{~N}$ içeriğine sahip olduğu; $\mathrm{C} / \mathrm{N}$ değerinin 22.36, demir, bakır, çinko ve Mangan içeriğinin ise sırası ile 217.2; 10.9; 30.6 ve $902.6 \mathrm{mg}$ $\mathrm{kg}^{-1}$ olduğu belirtilmiştir.

Özyazıcı (2013) tarafindan denemede kullanılan çay atığının \%2.23 N içeriğine sahip olup $\mathrm{C} / \mathrm{N}$ değerinin $24.70, \mathrm{pH}$ değerinin 5.04, elektriksel iletkenlik (EC) değerinin 2.604 $\mathrm{dS} \mathrm{m}{ }^{-1}$, fosfor içeriğinin $\% 0.176$, potasyum içeriğinin $\% 1.209$, $\mathrm{Fe}, \mathrm{Cu}, \mathrm{Zn}$ ve $\mathrm{Mn}$ içeriğinin ise sırası ile $684.84 ; 9.98 ; 20.87$ ve $1554.76 \mathrm{mg} \mathrm{kg}^{-1}$ olduğu belirtilmiştir.

Çay bitkisinde 1 da bahçeden 1 ton ürün kaldırılması ile ortalama $27 \mathrm{~kg} \mathrm{da}^{-1} \mathrm{~N}, 5.3 \mathrm{~kg} \mathrm{da}-1$ P ve $9.1 \mathrm{~kg} \mathrm{da}^{-1} \mathrm{~K}$ elementlerinin sömürüldüğü belirtilmiştir (Müftüoğlu ve ark. 2010). Bu değerlere dikkat edildiğinde bitkinin kendi atığından yapılacak olan kompost ile besin maddelerinin önemli bir kısmının karşılanabileceği görülmektedir.

\section{Tartışma ve Sonuç}

Elde edilen çay atığı kompostunun denemedeki yöntem uygulandığında 1 ay gibi kısa bir sürede elde edilebileceği belirlenmiştir. $\mathrm{Bu}$ kompostun özellikle çayın aldığı besin maddelerinin yine çay bitkisine döndürülmesi bakımından önemli olduğu görülmektedir. Elde edilen kompostun elektriksel iletkenlik değerinin kullanılan organik gübre ile ilişkili olduğu ancak çaylık bölgelerin çok yağışlı olması nedeni ile problem yaratmayacağı ayrıca kompostun özellikle $\mathrm{pH}$ değeri çok düşük olan bölgelerde kullanılmasının yarar sağlayacağı düşünülmektedir. Çay fabrikalarından elde edilen atıkların hepsinin kompost hale getirilmesi durumunda bile çay tarım alanlarının tamamına yetmeyeceği göz önünde bulundurulmalıdır. Elde edilen kompostun özelliklerini çay bahçelerinden alınan ham maddenin ve kullanılan katkı maddelerinin belirleyeceği unutulmamalıdır. Çay atıklarının kompostlaştırması amacıyla kontrollü koşulların oluşturulmasında ilk yatırım maliyetleri fazla bulunabilir. Ancak böyle bir düzeneğin belirli fabrikalarda öncelikle deneme amaçlı kurulması problemin çözülmesine yardımcı olacaktır.

\section{Kaynaklar}

Altun L (1998) Çay fabrikası lifsel artıklarını orman fidanlıklarında kompostlaştırılması ve bitkiler için öneminin araştırılması. KTÜ Fen Bilimleri Enstitüsü, Yayınlanmamış Yüksek Lisans Tezi, Trabzon.

Aşık BB, Kütük C (2012) Çay atığı kompostunun çim alanların oluşturulmasında kullanım olanağı. Uludağ Üniversitesi Ziraat Fakültesi Dergisi 26(2): 47-57.

Bilgin S, Koçer A, Yılmaz H, Acar M, Dok M (2016) Çay fabrikası atıklarının peletlenmesi ve pelet fiziksel özelliklerinin belirlenmesi. Gaziosmanpaşa Üniversitesi Ziraat Fakültesi Dergisi Sayı: 33 (Ek say1): 70-80.

Dok M (2014) Karadeniz Bölgesinin tarımsal atık potansiyeli ve bunlardan pelet yakıt olarak yararlanılması. Enerji Tarımı ve Biyoyakıtlar 4. Ulusal Çalıştayı, Samsun, s. 211-222.

Irmak ÜG, Müftüoğlu NM (2016) Farklı oranlarda kullanılan çay posasının marul bitkisi gelişimi üzerine etkisi. Bilinçli Sağlıklı Yaşam Dergisi Ocak 2016, Say1:12, ISSN 2149-147X, s. 164-172.

Jackson ML (1958) Soil Chemical Analysis. Verlag: Prentice Hall, Inc., Englewood Cliffs, NJ. 1958, 498 S. DM 39.40.

Kacar B (1987) Çayın Biyokimyası ve İşlenme Teknolojisi. Çay İşletmeleri Genel Müdürlüğ̈̈ Yayını No: 6, DSİ Matbaası, Ankara, s. 329 .

Kacar B, İnal A (2010) Bitki Analizleri (2. Baskı). Nobel Yayınları No: 1241, Ankara.

Kacar B, Kovancı İ, Atalay İZ (1980) Utilization of the tea waste products of tea factories in Agriculture. AÜZF Yılllğı 29(1): 158173.

Kacar B, Taban S, Kütük C (1996) Çay atıklarının zenginleştirilmiş organik gübreye dönüştürülerek kullanılması. AraştırmaGeliştirme-Uygulama Projesi (Kesin Rapor), Çay İşletmeleri Genel Müdürlüğ̈̈, Rize.

Kacar B, Taban S, Kütük C (2004) Çay atıklarının zenginleştirilmiş organik gübreye dönüştürülmesi. Türkiye 3. Ulusal Gübre Kongresi, Tarım-Sanayi-Çevre, Tokat, s. 805-814.

Kütük C (2000) Çay atığı kompostu ve atık mantar kompostunun yetiştirme ortamı bileşeni olarak süs bitkisi yetiștiriciliğinde kullanılması. MKÜ Ziraat Fakültesi Dergisi 5(1-2): 75-86.

Kütük C, Çaycı G, Baran A (1995) Çay atıklarının bitki yetiştirme ortamı olarak kullanılabilme olanakları. Tarım Bilimleri Dergisi 1(1): 35-40. 
Kütük C, Taban S, Kacar B, Samet H (1996) Etkinlikleri yönünden çay atığı ile ahır gübresi ve değişik kimyasal gübrelerin karşılaştırılması. Tarım Bilimleri Dergisi 2(3): 51-57.

Müftüoğlu NM, Özer SP, Tanyel G, Kabaoğlu A (2012a) Doğu Karadeniz Bölgesinde Çay Tarımı Yapılan Topraklarda Bazı Bitki Besin Maddelerinde Zamana Bağlı Olarak Meydana Gelen Değişmeler. Kriter Yayınevi, Hobyar Mh. Ankara Cad. Güncel Han No: 45/18-20 Fatih/İstanbul, ISBN: 978-605-4613-36-6, Sertifika No: 11413, s. 167.

Müftüoğlu NM, Mahmutoğlu H, Özer SP, Tanyel G, Kalcıŏ̆lu Z, Turna T, Yüce E (2012b) Çay Bitkisinin Verim ve Kalitesi Üzerine Bazı Toprak ve Bitki Özelliklerinin Etkisi. Kriter Yayınevi, Hobyar Mah. Ankara Cad. Güncel Han No: 45/18-20 Fatih/İstanbul, ISBN: 978-605-4613-35-9, Sertifika No:11413, s. 100.

Müftüoğlu NM, Türkmen C, Çıkılı Y (2014) Toprak ve Bitkide Verimlilik Analizler (2. Basım). Nobel Akademik Yayıncılık Eğitim Danışmanlık Tic. Ltd. Şti. Ankara Dağıtım Kültür Mah. Mithatpaşa Cad. No: 74 B01/02 Kızılay Ankara, ISBN: 978-605133-895-8, s. 218.

Müftüoğlu NM, Yüce E, Turna T, Kabaoğlu A, Özer SP, Tanyel G (2010) Çay Tarımı Yapılan Alanların Bazı Toprak ve Bitki Özelliklerinin Değerlendirilmesi. Ege Üniversitesi Ziraat Fakültesi Dergisi Özel Sayı ISSN 1018-8851, İzmir, s. 309-316.
Özyazıcı G (2013) Karadeniz Bölgesinde Organik Tarım Tekniklerinin Geliştirilmesi "Organik Çay İşleme Atıklarından Elde Edilen Kompostun Organik Çay Üretiminde Kullanılması". Proje Yürütücüsü: Dr. Gülen Özyazıcı, 2013. Proje Gelişme Raporu, Proje Numarası: BBOT-11-10, Raporun İlgili Olduğu Dönem: 01/01/2013-31/12/2013, Proje Yürütücüsü Kuruluș: 01/01/2013$31 / 12 / 2013$.

Resmî Gazete (2018) http://www.resmigazete.gov.tr/eskiler/2018/02/20180223-4.htm Erişim 4 Aralık 2018.

Yakupoğlu T, Özdemir N (2007) Erozyona uğramış topraklara uygulanan arıtma çamuru ve çay endüstrisi atığının toprakların mikro element içeriklerine etkileri. OMÜ Zir. Fak. Dergisi 22(2): 207-213.

Yalınkılıç MK, Altun L, Kalay Z (1996) Çay fabrikaları çay yaprağı artıklarının kompostlaştırılarak orman fidanlıklarında organik gübre olarak kullanılması. Ekoloji Dergisi 18: 28-32. 